\title{
KONSEP PENANGANAN PERMUKIMAN KUMUH KELURAHAN KOTABARU KOTA SERANG (Concept of Slum Handling in Kotabaru Serang City)
}

\author{
Laily Kurniasari*, Raldi Hendro Koestoer, dan Emirhadi Suganda \\ Fakultas Pasca Sarjana, Program Studi Kajian Ilmu Lingkungan, Universitas Indonesia, \\ Jl. Salemba Raya No. 6 Jakarta Pusat, 16424.
}

*Penulis korespondensi. Email: lailykurniasari@yahoo.co.id.

\author{
Diterima: 13 Mei 2017
}

Disetujui: 15 Maret 2018

\begin{abstract}
Abstrak
Salah satu dampak semakin tingginya jumlah penduduk di perkotaan adalah munculnya permukiman kumuh, termasuk yang terjadi di Kelurahan Kotabaru, kota Serang. Berbagai upaya penanganan permukiman kumuh telah lama dilakukan, namun kenyataannya secara keseluruhan program penanganan permukiman kumuh yang telah dilaksanakan hasilnya belum menunjukkan perubahan yang berarti dalam membantu penataan dan perbaikan permukiman kumuh. Untuk mengetahui penanganan permukiman kumuh yang sesuai maka perlu dilakukan analisis tingkat kekumuhan berdasarkan karakteristik lingkungan, ekonomi, dan sosial masyarakatnya dan menyusun konsep penanganan permukiman kumuh yang sesuai. Penelitian ini menggunakan pendekatan kualitatif dengan metode campuran untuk mengumpulkan data kualitatif dan kuantitatif. Hasil penelitian menjelaskan bahwa strata kekumuhan di permukiman Kotabaru terdiri dari kumuh sedang (RW 1 dan RW 2) dan kumuh berat (RW 3 dan RW 5). Tingkat kekumuhan yang berbeda membutuhkan penanganan yang berbeda pula, untuk wilayah kumuh sedang, penanganan dilakukan melalui peremajaan dengan land sharing. Untuk wilayah kumuh berat penanganan melalui pembangunan rumah susun.
\end{abstract}

Kata kunci: permukiman kumuh, permukiman berkelanjutan, tingkat kekumuhan, konsep penanganan.

\begin{abstract}
The increase in the urban population has led to various impacts, and it also occurs in Sub Kotabaru city of Serang. One consequence is the increasing demand for appropriate housing, but this increase is not offset by an increase in the amount of land in the city. Limitations of land in the city resulted in land prices high and not affordable by low-income people. They occupied the land with the designation not to settlements such as riverbanks, railroad tracks and lead to slums in urban areas. Various efforts to address the slum has long been done, but in fact the overall program management of slums that have been implemented the results have not shown significant changes in assisting the structuring and slum upgrading. To determine the proper handling of slums it is necessary to identify the level of squalor by environmental characteristics, economic, and social communities; and draft handling of slums. This study used a qualitative approach with a mix of methods to collect qualitative and quantitative data. The results of the study explained that the strata level of slum in Kotabaru consists of medium slum (RW 1 and $R W 2)$ and heavy slum (RW 3 and $R W 5$ ). Squalor different level requires different handling, anyway, to the slums being, handling through rejuvenation with land sharing. To the slums of heavy handling through the construction of flats.
\end{abstract}

Keywords: slum, sustainable settlements, level of slum, concept of handling.

\section{PENDAHULUAN}

Salah satu dampak dari pertumbuhan penduduk yang tinggi di kota adalah meningkatnya permintaan akan rumah yang layak huni, sehingga membutuhkan ketersediaan lahan permukiman yang lebih luas. Namun peningkatan kebutuhan akan lahan permukiman tidak diimbangi dengan peningkatan jumlah lahan di kota. Keterbatasan lahan di kota menyebabkan tingginya harga lahan sehingga tidak terjangkau oleh golongan Masyarakat Berpenghasilan Rendah (MBR). Akibatnya mereka menduduki lahan yang peruntukannya bukan untuk permukiman misalnya disepanjang rel kereta api, di bantaran sungai, di kolong jembatan atau menempati permukiman dengan kepadatan bangunan yang tinggi, sehingga memicu muculnya permukiman kumuh pada kawasan perkotaan. Untuk mengkaji permasalahan ini perlu dilakukan dengan pendekatan konsep pembangunan berkelanjutan.

Pembangunan berkelanjutan menurut Komisi Bruntland adalah pembangunan yang memenuhi kebutuhan generasi saat ini tanpa mengurangi kemampuan generasi mendatang untuk memenuhi kebutuhan mereka (Fauzi, 2004). Pembangunan berkelanjutan menurut Salim (2009) terdiri dari 3 pilar keberlanjutan. Pilar pertama adalah keberlanjutan lingkungan, berupa keseimbangan fungsi ekosistem dalam menopang sistem 
kehidupan alami yang menghidupi semua komponen lingkungan hidup manusia. Pilar kedua berupa keberlanjutan ekonomi, berupa proses ekonomi yang berjalan secara berlanjut (steady), dengan stabilitas ekonomi dan pertumbuhan produktivitas yang memperkaya kualitas kehidupan manusia. Berikutnya adalah pilar keberlanjutan sosial perilaku, dengan melibatkan peran serta masyarakat madani yang berdaya diri.

Pembangunan berkelanjutan di sektor permukiman menurut Kirmanto (2002) diartikan sebagai upaya untuk memperbaiki kondisi sosial, ekonomi dan kualitas lingkungan sebagai tempat hidup dan bekerja semua orang. Permukiman yang berkelanjutan harus memiliki ekonomi yang kuat, lingkungan yang serasi, tingkat sosial yang relatif setara penuh keadilan, kadar peran serta masyarakat yang tinggi, dan konservasi energi yang terkendali dengan baik (Budihardjo dan Sujarto, 2013). Inti pembangunan permukiman yang berkelanjutan merupakan upaya untuk meningkatkan kualitas hidup secara berkelanjutan. Dengan konsep pembangunan berkelanjutan maka dapat didesain suatu kawasan dengan lebih terarah. Sebagai contoh Ijong dkk (2017) telah menerapkan untuk desain kawasan tepian pantai perkotaan Tahuna.

Dengan pertambahan jumlah penduduk perkotaan yang tidak diimbangi dengan bertambahnya lahan perkotaan mengakibatkan munculnya permukiman kumuh. Permukiman kumuh menurut Kuswartojo (2005) yaitu permukiman yang padat, kualitas konstruksi rendah, prasarana, dan pelayanan minimal. Lembaga Cities Alliance memberikan pengertian permukiman kumuh merupakan bagian kota yang terabaikan sehingga mengakibatkan perumahan dan kondisi kehidupan masyarakatnya berada dalam status miskin (Anonim, 2008). Kawasan ini dapat terletak di tengah kota dengan kepadatan yang tinggi atau terbangun secara spontan di pinggiran kota.

Penanganan permukiman kumuh harus dapat memecahkan masalah kekumuhan dengan melihat karakteristik lingkungan, ekonomi, dan sosial masyarakatnya. Beberapa penelitian telah melaporkan upaya penanganan kawasan kumuh seperti Rahayu dkk (2009) yang melakukan kajian penataan dan rehabilitasi permukiman kumuh studi kasus kawasan bantaran sungai Code bagian utara, Yogyakarta. As'ari dan Fadjarani (2018) juga cukup komprehensif mengkaji kawasan permukiman kumuh di Kelurahan Bantarsari Kecamatan Bungursari Kota Tasikmalaya. Upaya penanganan permukiman kumuh pada tanah legal dan tanah ilegal akan berbeda. Penanganan permukiman kumuh pada tanah legal dapat dilakukan dengan peremajaan atau pemugaran.
Peremajaan dilakukan dengan land sharing atau land consolidation. Penanganan permukiman kumuh pada tanah ilegal dilakukan dengan permukiman kembali yaitu dengan pembangunan rumah susun.

Kelurahan Kotabaru adalah kelurahan di Kota Serang yang mengalami kekumuhan. Berbagai upaya penanganan permukiman kumuh di Kelurahan Kotabaru telah lama dilakukan melalui beberapa program yang diselenggarakan oleh pemerintah. Namun kenyataannya secara keseluruhan program-program penanganan permukiman kumuh yang telah dilaksanakan hasilnya belum menunjukkan perubahan yang berarti dalam membantu penataan dan perbaikan permukiman kumuh di Kelurahan Kotabaru. Oleh karena itu perlu disusun konsep penanganan permukiman kumuh yang sesuai dengan kondisi fisik dan karakteristik masyarakat setempat.

Penelitian ini bertujuan untuk menganalisis tingkat kekumuhan Kelurahan Kotabaru dilihat dari aspek lingkungan, aspek ekonomi, dan aspek social, serta untuk dapat menyusun konsep penanganan permukiman kumuh di Kelurahan Kotabaru.

\section{METODE PENELITIAN}

\section{Waktu dan Lokasi}

Penelitian telah dilakukan pada bulan Februari-Desember 2016. Lokasi penelitian adalah permukiman kumuh yang ada di Kelurahan Kotabaru yaitu RW 1 (Kampung Calung), RW 2 (Kampung Kebonsayur), RW 3 (Kampung Pasar) dan RW 5 (Kampung Magersari). Kelurahan Kotabaru secara administrasi masuk di dalam wilayah Kota Serang yang mempunyai jarak \pm 1 km dari pusat Kota Serang. Lokasi penelitian adalah permukiman kumuh di Kelurahan Kotabaru Kota Serang. Lokasi penelitian dapat dilihat pada Gambar 1.

\section{Prosedur}

Penelitian ini menggunakan pendekatan kuantitatif. Metode penelitian adalah kuantitatif. Penelitian ini didukung oleh data kuantitatif dan data kualitatif yang dikuantitatifkan. Populasi dalam penelitian ini ada dua yaitu: (1) bangunan rumah dan prasarana permukiman yang ada di permukiman kumuh Kelurahan Kotabaru (RW 1, 2, 3 dan 5). Metode pengumpulan data dilakukan dengan mengkombinasikan hasil pengamatan dengan data sekunder. Gambar, berupa peta, digunakan untuk mengidentifikasi kondisi rumah dan prasarana permukiman yang tersedia; (2) Kepala Keluarga (atau pendamping) yang tinggal di permukiman kumuh Kelurahan Kotabaru (RW 1, 2, 3 dan 5). Metode pengambilan data untuk populasi penelitian ini dilakukan dengan survei. 


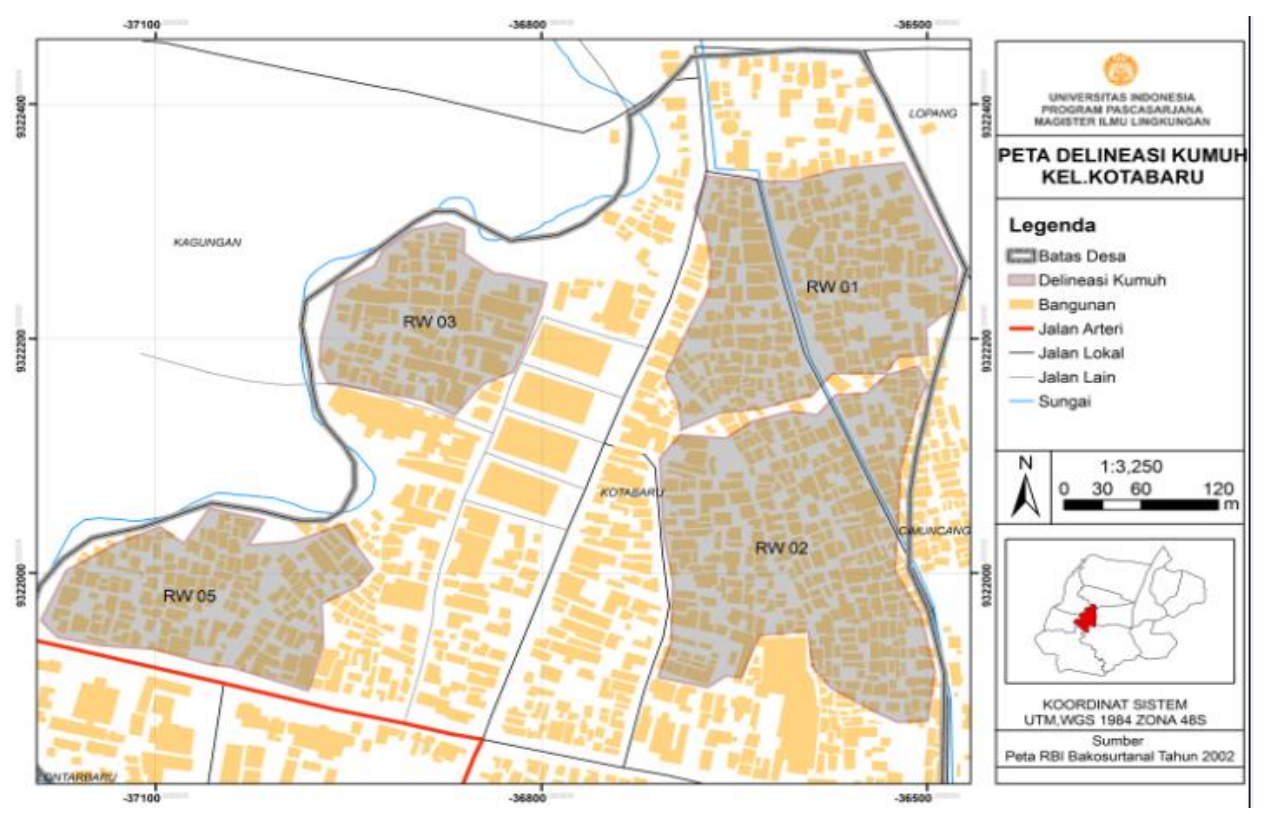

Gambar 1. Lokasi penelitian.

Tabel 1. Jumlah Sampel per RW.

\begin{tabular}{lcc}
\hline RW & Jumlah KK & Jumlah Sampel \\
\hline 1 & 336 & 23 \\
2 & 406 & 28 \\
3 & 222 & 15 \\
5 & 388 & 27 \\
Total & 1352 & 93 \\
\hline
\end{tabular}

Sumber: Perhitungan peneliti (2016).

Penentuan jumlah sampel dengan menggunakan rumus Slovin. Batas toleransi kesalahan dalam penelitian ditentukan $10 \%$. Dengan menggunakan rumus Slovin didapatkan jumlah sampel sebanyak $93 \mathrm{KK}$, dengan detail sampel diberikan pada Tabel 1. Untuk jumlah sampel sub populasi atau masing-masing RW prosedur pengambilan sampel dengan metode proportional random sampling dan pemilihan sampel berdasarkan simple random sampling. Berdasarkan proportional random sampling maka akan didapatkan sampel per RW secara proporsional perbandingannya dengan RW lainnya.

\section{Analisis Data}

Analisis data dilakukan dengan menyajikan hasil data dari tema-tema, yang ditentukan berdasarkan indikator masing-masing variabel penelitian, secara kualitatif. Selanjutnya hasil data kuantitatif dipilih dengan tema-tema sejenis yang kemudian dibandingkan untuk dianalisis bersama. Data kuantitatif digunakan untuk memperkaya peneliti dalam menganalisis data kualitatif yang ada.

Identifikasi tingkat kekumuhan dilakukan dengan menggunakan metode skoring dengan mengacu pada Peraturan Menteri Pekerjaan Umum dan Perumahan Rakyat No 2/ PRT/ M/ 2016 tentang Peningkatan Kualitas terhadap Perumahan
Kumuh dan Permukiman Kumuh dengan melihat aspek lingkungan, ekonomi, dan sosial. Proses penilaian untuk hasil setiap variabel berdasarkan klasifikasi yang telah dikemukakan menggunakan ambang batas yang dikategorikan ke dalam penilaian berat, sedang, dan ringan. Klasifikasi dalam setiap variabel diinterpretasikan ke dalam nilai bobot 1 (baik), 3 (cukup), 5 (buruk) nilai tertinggi 5 dan nilai terendah 1 , semakin tinggi nilai skoring maka semakin berat tingkat kekumuhan.

Penilaian tingkat kekumuhan dibagi menjadi 3 yaitu Kumuh Berat (K3) dengan nilai 71-95, Kumuh Sedang (K2) dengan nilai 45-70 dan Kumuh Ringan (K1) dengan nilai 19-44. Untuk penilaian berdasarkan pertimbangan lain yang terdiri dari aspek ekonomi dan sosial yaitu pertimbangan lain tinggi bila memiliki nilai 11-15, pertimbangan lain sedang bila memiliki nilai 6-10 dan pertimbangan lain rendah bila memiliki nilai 15 .

Berdasarkan penilaian yang telah dilakukan berdasarkan formula penilaian tersebut, selanjutnya lokasi permukiman kumuh dapat dikelompokkan dalam berbagai klasifikasi penanganan.

\section{HASIL DAN PEMBAHASAN}

Kelurahan Kotabaru secara administrasi masuk di dalam wilayah Kota Serang yang mempunyai jarak $\pm 1 \mathrm{~km}$ dari pusat Kota Serang. Letaknya yang berada di pusat kota dan berbatasan dengan pusat perdagangan dan jasa menyebabkan permukiman Kotabaru berkembang lebih cepat daripada wilayah lainnya. Adanya aktifitas perdagangan dan jasa berdampak pada meningkatnya kebutuhan akan tempat tinggal. Permukiman Kotabaru yang sudah padat oleh 
penduduk asli semakin padat dengan adanya penduduk pendatang. Hal ini ber akibat semakin banyak tumbuh bangunan-bangunan di Kotabaru yang membuat permukiman semakin padat dan tidak beraturan sehingga menyebabkan kekumuhan dibeberapa RW yang ada di Kotabaru. Diperlukan penanganan untuk mencegah semakin meluasnya kawasan kumuh. Untuk menentukan konsep penangannya maka dilakukan identifikasi tingkat kekumuhan dan analisis partisipasi masyarakat.

\section{Penilaian Tingkat Kekumuhan Aspek lingkungan}

Penilaian tingkat kekumuhan berdasarkan aspek lingkungan dinilai dari kondisi bangunan rumah dan kondisi sarana prasarana permukiman. Aspek kondisi bangunan rumah dilihat dari ketidakteraturan bangunan, kepadatan bangunan, dan kualitas bangunan. Aspek kondisi sarana prasarana dinilai dari kondisi dan ketersediaan sarana dan prasarana lingkungan permukiman. Sarana dan prasarana yang dinilai meliputi kondisi dan ketersediaan prasarana jalan, air minum, drainase, pengelolaan limbah, pengelolaan persampahan, dan ketersediaan sarana prasarana proteksi kebakaran.

Berdasarkan hasil analisis seperti disajikan pada Gambar 2, lingkungan RW 1 dan RW 2 memiliki tingkat kekumuhan sedang, sedangkan RW 3 dan RW 5 tingkat kekumuhan berat. Tingkat kekumuhan sedang berada pada lokasi yang terletak berbatasan dengan kawasan perdagangan dan jasa Royal, sedangkan lokasi yang termasuk kumuh berat berada pada lokasi yang berbatasan dengan sungai Cibanten.

Lingkungan RW 1 dan RW 2 memiliki karakteristik lingkungan yang hampir sama. Kumuh pada RW 1 dan RW 2 termasuk kumuh sedang, tetapi jika dilihat dari analisis skoring yang telah dilakukan diketahui bahwa kekumuhan RW 2 lebih parah daripada RW 1. Variabel yang menyebabkan kekumuhan hampir sama, hanya besarannya yang berbeda. Berdasarkan kondisi fisik rumah, lebih banyak rumah di RW 2 yang mengalami kerusakan daripada di RW 1. Rumah di RW 2 yang rusak sebanyak $72 \%$, sedangkan rumah di RW 1 yang rusak sebanyak $47 \%$.

Lingkungan RW 3 dan RW 5 memiliki tingkat kekumuhan berat. Letak lingkungan RW 3 dan RW 5 yang berbatasan dengan sungai Cibanten berpengaruh terhadap terjadinya kekumuhan. Banyak tumbuh permukiman liar di bantaran sungai dengan kondisi rumah nonpermanen yang tidak layak huni. Variabel penyebab kekumuhan yang membedakan RW 3 dan RW 5 adalah drainase dan pengelolaan limbah. Lingkungan RW 3 memiliki saluran drainase yang lebih banyak daripada drainase yang ada di RW 5. Pengelolaan limbah di RW 3 lebih baik daripada di RW 5. Jumlah rumah tangga yang memiliki jamban tidak terhubung dengan tangki septik di lingkungan RW 5 lebih banyak daripada di lingkungan RW 3 yaitu sebesar $62 \%$ pada RW 3, dan $82 \%$ pada RW 5.

Jika dilihat secara menyeluruh penyebab kekumuhan paling parah di Kelurahan Kotabaru adalah masalah sampah. Di seluruh RW belum ada sarana dan prasarana persampahan yang memadai. Sebagian besar masyarakat membuang sampah di sungai atau saluran drainase dan saluran irigasi, menyebabkan terjadinya pendangkalan sungai dan berakibat terjadinya banjir pada musim hujan pada beberapa wilayah. Banjir terparah terjadi setiap tahun di wilayah RW 5 dengan ketinggian air mencapai 4,5 meter. Selain masalah pendangkalan sungai, banjir yang terjadi di RW 5 juga disebabkan oleh letak RW 5 yang berada lebih rendah daripada wilayah sekitarnya.

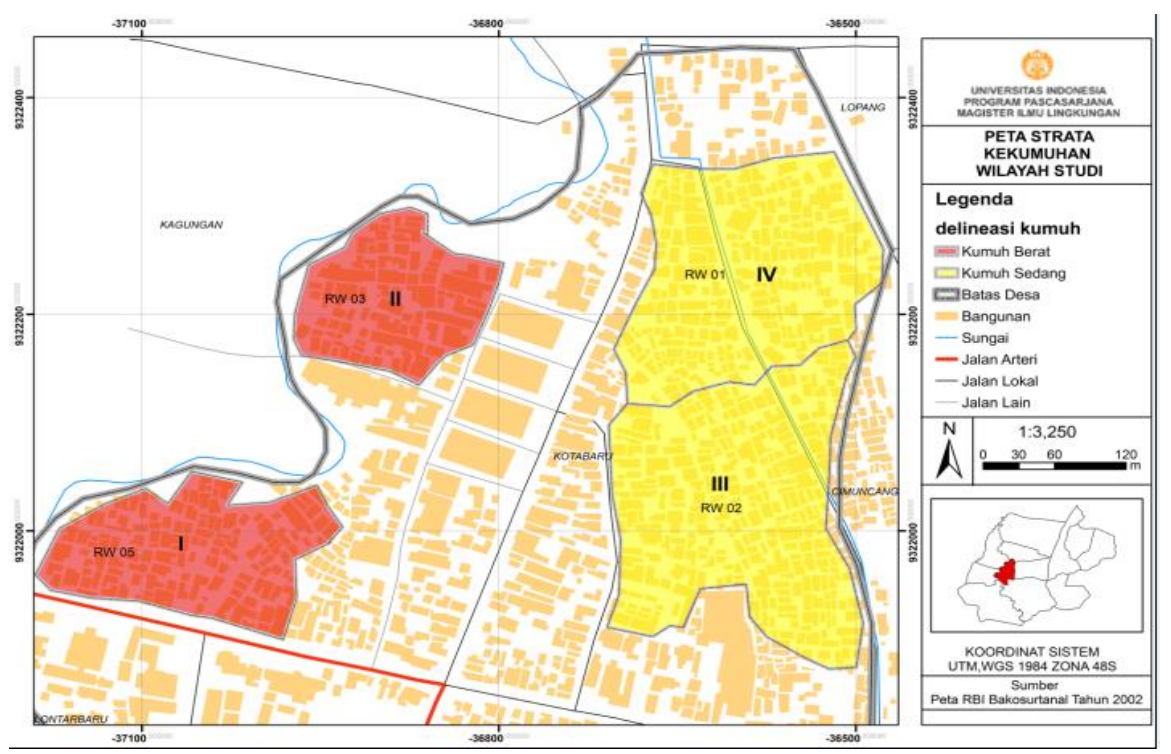

Gambar 2. Strata kekumuhan tiap RW di Kelurahan Kotabaru. Sumber: Hasil analisis (2016). 
Penyebab kekumuhan di Kelurahan Kotabaru selain sampah yaitu pengelolaan air limbah. Semua lokasi memiliki pengelolaan limbah dengan tingkat kekumuhan berat yaitu pengelolaan limbah tidak memenuhi ketentuan teknis, jamban tidak terhubung dengan saluran tangki septik dan belum ada sistem pengelolaan limbah setempat atau terpusat. Lingkungan RW 5 memiliki pengelolaan limbah terparah daripada lainnya. Letaknya yang berbatasan dengan sungai Cibanten berpengaruh terhadap tersedianya sarana pengelolaan limbah. Masyarakat yang tinggal di sempadan sungai membuang limbahnya langsung ke sungai, kondisi ini akan membahayakan, karena dapat menimbulkan pencemaran dan sumber berbagai penyakit.

Selain tingkat kekumuhan legalitas lahan menjadi pertimbangan penting dalam menentukan bentuk penanganan kumuh. Penanganan kumuh pada lahan legal dan lahan ilegal akan berbeda bentuk penanganannya. Bangunan di Kelurahan Kotabaru sebagian tidak memiliki kejelasan status penguasaan tanah, baik milik sendiri atau milik pihak lain. Paling banyak ditemukan bangunan ilegal di RW 3 dan RW 5, yaitu bangunanbangunan yang berdiri di sepanjang sempadan sungai Cibanten. Berdasarkan status legalitas lahan maka bentuk penanganan kumuh di RW 1 dan RW 2 serta RW 3 dan RW 5 akan berbeda penanganannya.

\section{Aspek pertimbangan lain}

Beberapa aspek pertimbangan lain digunakan untuk menentukan skala prioritas penanganan kumuh. Aspek pertimbangan lain meliputi nilai strategis lokasi, kependudukan, potensi ekonomi, sosial, dan budaya.

1. Nilai Strategis Lokasi

Kelurahan Kotabaru memiliki letak yang strategis, yaitu berbatasan langsung dengan kawasan perdagangan dan jasa kota Serang. Lokasinya yang strategis yaitu berada di pusat kota dan berbatasan dengan kawasan perdagangan dan jasa, menjadikan Kelurahan Kotabaru tumbuh berkembang dengan cepat. Jumlah penduduknya meningkat setiap tahun karena banyaknya warga pendatang, sehingga menyebabkan semakin padatnya bangunan di Kelurahan Kotabaru. Tingkat kepadatan bangunan yang tinggi merupakan salah satu yang menyebabkan kekumuhan di Kelurahan Kotabaru.

2. Kependudukan

Masyarakat Kelurahan Kotabaru merupakan campuran antara penduduk asli dan pendatang dari berbagai daerah di Indonesia. Selain dari pribumi, permukiman kumuh Kelurahan
Kotabaru juga dihuni oleh penduduk dari etnis Tionghoa. Kepadatan penduduk tertinggi berada di RW 3 yaitu 655 jiwa/ hektar dan terendah berada di RW 1 yaitu 351 jiwa/ hektar. Secara keseluruhan kepadatan penduduk di Kelurahan Kotabaru tergolong tinggi. Semakin banyak penduduk semakin banyak lahan yang dibutuhkan untuk tempat tinggal, ketersediaan lahan yang terbatas mengakibatkan permukiman semakin padat oleh bangunan, menyebabkan daya dukung lingkungan menurun, sehingga terjadi kekumuhan.

3. Potensi Ekonomi

Adanya peluang kegiatan ekonomi berupa aktivitas perdagangan dan jasa di lingkungan sekitar permukiman kumuh Kotabaru, mendorong masyarakat Kotabaru untuk ikut serta dalam aktivitas ekonomi yang berkembang di dalamnya. Sebagian besar Kepala Keluarga di Kelurahan Kotabaru bekerja di sektor perdagangan dan jasa. Ada yang bekerja sebagai buruh toko, pedagang kaki lima, dan pembantu rumah tangga. Aktifitas perdagangan terjadi tidak hanya di Royal dan Pasar Lama, tetapi ada sebagian masyarakat yang mengembangkan tempat hunian mereka sebagai lokasi berdagang. Akibatnya fungsi utama Kelurahan Kotabaru sebagai kawasan permukiman beralih fungsi menjadi kawasan campuran, yaitu selain sebagai tempat hunian juga difungsikan sebagai tempat berdagang/usaha. Berdasarkan fenomena tersebut kita dapat lihat bahwa aktivitas kawasan sekitar dapat mempengaruhi karakteristik perekonomian suatu kawasan.

4. Potensi Sosial

Tingkat partisipasi masyarakat dalam penanganan permukiman kumuh di Kelurahan Kotabaru terdiri dari tingkat partisipasi sedang dan tingkat partisipasi rendah. Tingkat partisipasi rendah berada pada RW 5, sedangkan tingkat partisipasi sedang berada pada lingkungan RW 1,2, dan 3. Tingkat partisipasi masyarakat di Kelurahan Kotabaru dapat dilihat pada Tabel 2.

Partisipasi masyarakat pada saat tahap pelaksanaan lebih besar daripada partisipasi masyarakat pada tahap perencanaan dan pemeliharaan.

Tabel 2. Tingkat partisipasi masyarakat.

\begin{tabular}{lllc}
\hline No & Lokasi & Skor & Tingkat partisipasi \\
\hline 1 & RW 1 & $43,6 \%$ & Sedang \\
2 & RW 2 & $37,0 \%$ & Sedang \\
3 & RW 3 & $35,5 \%$ & Sedang \\
4 & RW 5 & $31,0 \%$ & Rendah \\
\hline
\end{tabular}

Sumber: Hasil analisis (2016). 
Ketidakterlibatan masyarakat pada saat tahap perencanaan sebagian besar karena tidak mendapatkan informasi ketika akan diadakan pertemuan atau kegiatan perencanaan. Sebagian kecil lainnya ketidakterlibatan mereka dalam kegiatan perencanaan karena kesibukan atau urusan keluarga.

5. Potensi Budaya

Warisan budaya yang masih dijalankan dalam rangka membersihkan lingkungan hingga saat ini adalah budaya pada umumnya masyarakat di Indonesia yaitu adanya kegiatan gotongroyong. Kegiatan gotong-royong dilakukan dalam kegiatan kerja bakti membersihkan lingkungan. Namun kegiatan gotong-royong membersihkan lingkungan tidak rutin dilakukan setiap bulannya hanya dilakukan pada waktu-waktu tertentu saja. Berdasarkan karakteristik permukiman kumuh Kotabaru dilihat dari aspek, ekonomi, dan sosial, maka rekap penilaian tingkat kekumuhan Kelurahan Kotabaru masing-masing RW dapat dilihat pada Tabel 3.

\section{Konsep Penanganan Permukiman Kumuh Kelurahan Kotabaru}

Berdasarkan analisis tingkat kekumuhan, permukiman kumuh Kotabaru masuk dalam kategori kumuh berat dan sebagian kecil menempati lahan dengan status ilegal. Pola penanganan kumuh yang dapat dilakukan adalah peremajaan yaitu dengan melakukan perombakan dan penataan mendasar secara menyeluruh meliputi rumah dan prasarana, sarana, dan utilitas umum perumahan dan permukiman.
Peremajaan dilakukan untuk mewujudkan kondisi permukiman yang lebih baik gunamelindungi keselamatan dan keamanan penghuni danmasyarakat sekitar melalui pembongkaran dan penataan secara menyeluruh terhadap rumah, prasarana, sarana,dan/atau utilitas umum. Penanganan kumuh dilakukan dengan penempatan kembali kegiatan permukiman di atas lokasi asal dengan melakukan penataan rumah dan sarana prasarana permukiman.

Alternatif konsep penanganan permukiman kumuh dengan peremajaan dilakukan melalui Land Sharing Peremajaan permukiman kumuh dengan Land Sharing dipilih karena tingkat pemilikan lahan cukup tinggi yang dibuktikan dengan adanya surat pemilikan/penguasaan atas lahan yang ditempatinya secara sah dengan luasan yang terbatas, dan tata letak permukiman tidak terpola. Konsep penataan kembali melalui land sharing tersebut, masyarakat yang mempunyai surat kepemilikan lahan yang sah akan mendapatkan kembali lahannya dengan memperhitungkan kebutuhan untuk sarana dan prasarana umum. Pemerintah akan membayar ganti rugi lahan milik masyarakat yang digunakan untuk penambahan fasilitas umum.

Penanganan permukiman kumuh untuk masyarakat yang bertempat tinggal di bantaran sungai yaitu dengan permukiman kembali. Pertimbangan dipilihnya penanganan kumuh dengan permukiman kembali yaitu bahwa lokasi berada pada lahan ilegal yaitu bantaran sungai, tidak memiliki potensi pemanfaatan yang lebih baik dari fungsi yang ditetapkan, dan secara lingkungan

Tabel 3. Rekapitulasi penilaian kekumuhan Kotabaru.

\begin{tabular}{|c|c|c|c|c|c|}
\hline \multirow[t]{2}{*}{ No } & \multirow[t]{2}{*}{ Variabel } & \multicolumn{4}{|c|}{ Bobot } \\
\hline & & RW 1 & RW 2 & RW 3 & RW 5 \\
\hline \multicolumn{6}{|c|}{ Karakteristik Lingkungan } \\
\hline \multirow[t]{4}{*}{1} & Kondisi bangunan rumah & 7 & 9 & 13 & 13 \\
\hline & Keteraturan bangunan & 1 & 1 & 3 & 3 \\
\hline & Kepadatan bangunan & 5 & 5 & 5 & 5 \\
\hline & Kualitas bangunan & 1 & 3 & 5 & 5 \\
\hline \multirow[t]{7}{*}{2} & Prasarana lingkungan & 56 & 56 & 64 & 68 \\
\hline & Prasarana jalan & 4 & 4 & 8 & 8 \\
\hline & Ketersediaan air minum & 4 & 4 & 4 & 4 \\
\hline & Saluran drainase & 15 & 15 & 19 & 21 \\
\hline & Pengelolaan limbah & 8 & 8 & 8 & 10 \\
\hline & Pengelolaan persampahan & 15 & 15 & 15 & 15 \\
\hline & Proteksi kebakaran & 10 & 10 & 10 & 10 \\
\hline \multicolumn{2}{|c|}{ Total } & 63 & 65 & 77 & 81 \\
\hline \multicolumn{2}{|c|}{ Tingkat kekumuhan } & $\mathrm{K} 2$ & $\mathrm{~K} 2$ & K3 & K3 \\
\hline \multicolumn{2}{|c|}{ Legalitas lahan } & $(-)$ & $(-)$ & $(-)$ & $(-)$ \\
\hline \multicolumn{6}{|c|}{ Pertimbangan Lain } \\
\hline 1 & Nilai strategis lokasi & 5 & 5 & 5 & 5 \\
\hline 2 & Kependudukan & 5 & 5 & 5 & 5 \\
\hline 3 & Potensi ekonomi, sosial, budaya & 1 & 1 & 1 & 1 \\
\hline \multicolumn{2}{|c|}{ Sub Total } & 11 & 11 & 11 & 11 \\
\hline
\end{tabular}

Sumber : Hasil analisis (2016). 
memberikan dampak negatif yang lebih besar apabila tetap dipertahankan.

Untuk penanganan kumuh RW 3 dan RW 5 dengan banyaknya rumah yang berada di bantaran sungai dengan status kepemilikan lahan ilegal maka penanganan permukiman kumuh yang dilakukan dengan pembangunan rumah susun. Rumah susun di bangun di lingkungan RW 3 dan RW 5, dengan pertimbangan bahwa lokasi masih tetap berada di lingkungan tempat tinggal masyarakat sebelumnya dan dekat dengan lokasi tempat mereka bekerja. Masyarakat yang memiliki surat kepemilikan lahan akan mendapatkan kembali unit rumah dengan besaran yang sudah diperhitungkan sesuai dengan hasil kesepakatan.

\section{KESIMPULAN}

Kesimpulan dari penelitian ini adalah permukiman kumuh Kotabaru berdasarkan analisis skoring menunjukkan kondisi kumuh sedang dan kumuh berat. Tingkat kekumuhan dan legalitas lahan menjadi pertimbangan konsep penanganan. Konsep penanganan permukiman kumuh berdasarkan tingkat kekumuhan dan karakteristik sosial ekonomi masyarakat kumuh Kotabaru adalah konsep peremajaan melalui land sharing dan pembangunan rumah susun.

\section{DAFTAR PUSTAKA}

Anonim, 2008. Cities Without Slums. Cities Alliance. Washington DC: York Graphic Services
As'ari, R., dan Fadjarani, S., 2018. Penataan Permukiman Kumuh Berbasis Lingkungan, Jurnal Geografi, 15(1):56-67

Budiharjo, E. dan Sujarto, D., 2013. Kota Berkelanjutan (Sustainable City). Alumni. Bandung.

Fauzi, A., 2004. Ekonomi Sumberdaya Alam dan Lingkungan. Jakarta: PT. Gramedia PustakaUtama.

Ijong, J.F., Kumurur, V.A., dan Wuisang, C.E.F., 2017. Penerapan Konsep Kota Berkelanjutan Pada Desain Kawasan Tepian Pantai Perkotaan Tahuna. Jurnal Fraktal, 2(2): 31-40.

Kirmanto, D., 2002. Pembangunan Perumahan dan Permukiman yang Berwawasan Lingkungan Strategis dalam Pencegahan Banjir di Perkotaan. http://alramadona.blog.ugm.ac.id/ 2008/08/27/permasalahanpermukimanperkotaan (diakses 1 Maret 2015).

Kuswartojo, T., 2005. Perumahan dan Pemukiman Di Indonesia. Bandung: Institut Teknologi Bandung

Rahayu, T., Sudaryono, dan Baiquni, M., 2003. Evaluasi Program Penataan dan Rehabilitasi Permukiman Kumuh Studi Kasus Kawasan Bantaran Sungai Code Bagian Utara, Yogyakarta. J. Manusia \& Lingkungan, 10(2):53-62.

Salim, E., 2009. Penganugerahan Doktor Kehormatan Kepada Prof. DR. Emil Salim. Bandung: ITB. 